This work is licensed under a Creative Commons Attribution 4.0 International License.

Ovaj rad dostupan je za upotrebu pod međunarodnom licencom Creative Commons Attribution 4.0.

https://doi.org/10.31820/f.31.1.9

Ana Mihaljević

\title{
PREVOĐENJE LATINSKOGA ABLATIVA APSOLUTNOGA U HRVATSKOGLAGOLJSKIM TEKSTOVIMA $^{1}$
}

dr. sc. Ana Mihaljević, Filozofski fakultet, ana.mihaljevic35@gmail.com, Pula

izvorni znanstveni članak

UDK 811.163.1'366.546

rukopis primljen: 15. veljače 2019.; prihvaćen za tisak: 31. svibnja 2019.

U radu se analizira prevođenje latinske konstrukcije ablativ apsolutni u odabranim hrvatskoglagoljskim tekstovima prevedenim s latinskoga. Ablativ apsolutni u prijevodnim se tekstovima najčešće prevodi hrvatskim crkvenoslavenskim apsolutnim konstrukcijama u dativu ili instrumentalu. Dativ je apsolutni starija konstrukcija, čija pojava u tekstovima može poslužiti $i$ za dataciju prijevoda. Instrumental se u prijevodima pojavljuje jer ga prevoditelji doživljavaju kao hrvatsku crkvenoslavensku istovrijednicu ablativa. Pri prijevodu ablativa apsolutnoga mnogo se češće pojavljuju apsolutne konstrukcije nego zavisne surečenice, koje su danas najčešće prijevodne istovrijednice te konstrukcije kako bi prijevod bio što vjerniji izvorniku. Pri prevođenju ablativa apsolutnoga apsolutnim konstrukcijama vjerno se oponaša red riječi izvornika. U radu se analiziraju načini prevođenja te konstrukcije te uporaba različitih participa kao istovrijednica latinskim participima koji su dio te konstrukcije.

Ključne riječi: hrvatski crkvenoslavenski; ablativ apsolutni; dativ apsolutni; instrumental apsolutni

1 Tekst je nastao na temelju dorađene autoričine doktorske disertacije (Mihaljević 2018). 


\section{Uvod}

Ablativ apsolutni (ablativus absolutus) latinska je apsolutna konstrukcija ${ }^{2}$ koja se sastoji od imenske riječi i participa u ablativu. U tradicionalnim se gramatikama navodi da u toj konstrukciji imenska riječ u ablativu dobiva ulogu subjekta, a particip ulogu predikata. ${ }^{3} \mathrm{Na}$ suvremeni se hrvatski jezik može prevesti zavisnom rečenicom (vremenskom, uzročnom, pogodbenom i dopusnom ovisno o smislu rečenice), glagolskim prilogom sadašnjim i prošlim, prijedložnim izrazom ili nezavisnom rečenicom, međutim, njezino je značenje najčešće ipak vremensko ${ }^{4}$. U latinskoj se konstrukciji najčešće pojavljuju particip prezenta aktivnoga ili perfekta pasivnoga, a iznimno se pojavljuje i particip futura aktivnoga ${ }^{5}$. Particip prezenta na suvremeni hrvatski najčešće se prevodi nesvršenim glagolom jer obično označava radnju koja se događa istodobno s radnjom glavnoga glagola, a particip perfekta svršenim glagolom jer obično označava radnju koja se događa prije radnje glavnoga glagola. ${ }^{6}$ Obično imenica koja je dio ablativa apsolutnoga nije subjektom ostatka rečenice iako je to rijetko moguće. Budući da u hrvatskome crkvenoslavenskom ne postoji ablativ kao zaseban padež, ne postoji formalni korespondent latinskoj konstrukciji ablativa apsolutnoga. U crkvenoslavenskome, međutim, postoji konstrukcija dativa apsolutnoga, koja se katkad pojavljuje kao prijevodna istovrijednica. Kao prijevod se latinske konstrukcije pojavljuju i konstrukcije s instrumentalom za ablativ. Instrumental je padež koji pokriva velik broj značenja ablativa u latinskome ${ }^{7}$, pa ne čudi njihova pojava u prijevodu ablativa apsolutnoga. Instrumental apsolutni nije izvorna

2 O razvoju i značajkama ablativa apsolutnoga v. Ruppel (2012), Müller-Lancé (1994).

3 Gortan, Gorski, Pauš (2005: 246).

4 Ruppel (2012: 206) smatra da je jedna od mogućih definicija apsolutne konstrukcije u latinskome da je riječ o vremenskome značenju izraza čija glavna imenica nema vremensko značenje: „I shall work on the premise that an 'absolute' construction is a nominal phrase of temporal dimensions whose head noun does not have such dimensions, or for short: a temporal expression with a non-temporal head."

5 Gortan, Gorski, Pauš (2005: 246): „U klasičnoj prozi particip futura aktiva rijetko dolazi u ablativu apsolutnom."

6 Gortan, Gorski, Pauš (2005: 248): „Particip prezenta prevodi se nesvršenim glagolom, a particip perfekta pasiva svršenim."

7 „Kako je došlo do zamjene dativa instrumentalom, nije teško utvrditi. Ponajprije, instrumental se sam od sebe pri prevođenju s latinskog mogao nametnuti prevodiocu kao ekvivalent za ablativ. A pri tom su mogli pomoći i primjeri koji su već postojali u staroslavenskom (i crkvenoslavenskom) jeziku..." (Tandarić 1983: 77). 
crkvenoslavenska konstrukcija, nego je nastala pod utjecajem latinskoga izvornika. Osim apsolutnih konstrukcija u hrvatskim crkvenoslavenskim tekstovima prevedenima s latinskoga kao prijevod ablativa apsolutnoga pojavljuje se i vremenska rečenica koja je i danas česta prijevodna istovrijednica.

Korpus tekstova iz kojih su analizirani primjeri ablativa apsolutnoga uključuje apokrifne tekstove: Nikodemovo evandelje (Ev. Nicod. u FgNicod), hagiografije: Čtenie svete Margarite (Lectio s. Margaritae u COxf), Čistilište svetoga Patricija (De s. Patricio u COxf), Život Marije Magdalene (De s. Maria Magdalena u CŽg i CIvan) ${ }^{8}$; biblijske knjige ${ }^{9}$ : Estera $\left(\text { Est u } \mathrm{BrN}_{2}\right)^{10}$, Knjige o Makabejcima (1Mach i 2Mach u BrVO) ${ }^{11}$, brevijarske službe: Služba u čast sv. Antunu Padovanskome (S. Antonii de Padua u $\left.\mathrm{BrN}_{2}\right)^{12}$ i Služba u čast sv. Thomasu Becketu (Lectio in festo s. Thomae episc. et mart. u BrVO i BrBer $\left.{ }_{2}\right)^{13}$ te odabrane primjere iz građe za Rječnik crkvenoslavenskoga jezika hrvatske redakcije iz tekstova: Služba u čast sv. Franji (In s. Francisci u BrVat ${ }_{6}$ ), Homilija sv. Grgura pape (Hom. s. Gregorii papae u $\mathrm{BrVO}$ i $\mathrm{BrN}_{2}$ ), Apokrif o prekrasnome Josipu (Lectio de Josepho u COxf), Homilija sv. Jeronima (Hom. s. Hyeronimi u $\mathrm{BrN}_{2}$ ), Oracija (Or. u CPar i MVat ${ }_{4}$ ), Na Uznesenje Blažene Djevice Marije (In assumptione BVM u $\mathrm{BrN}_{2}$ ), Govor sv. Jeronima (Sermo s. Hieronymi presb. u $\mathrm{BrN}_{2}$ ), Rubrika (Rub. u BrVO), Mučenje sv. Jurja (Mart. s. Georgii u FgGeorg). ${ }^{14}$ U Spurná (2004) analizirano je 60 primjera konstrukcije iz Regule sv. Benedikta (Reg. s. Benedicti u RegBen), koja je i u građi za Rječnik crkvenoslavenskoga jezika hrvatske redakcije. Primjeri se iz toga teksta navode samo onda kad su osobito zanimljivi. Analizirani su tekstovi iz razdoblja od 14. do 16. st., što ne znači da su tekstovi tada i prevedeni jer je kod nekih vjerojatno riječ o ranijemu prijevodu.

$\mathrm{Niz}$ je radova o apsolutnim konstrukcijama iz perspektive slavenskih jezika. Opširnu je studio o dativu apsolutnome u slavenskim jezicima napisao Stanislav (1933/1934). O prevođenju je ablativa apsolutnoga u

\footnotetext{
8 Transliteracija i latinski tekst iz Mihaljević, A. (2014).

9 Latinski tekst Vulgate preuzet je sa stranice http://www.drbo.org/lvb/index.htm i usklađen je s klasičnom latinskom ortografijom.

10 O tekstu je pisala Badurina Stipčević (2012).

11 O tekstovima je pisala Badurina Stipčević (2006, 2009).

12 Vlastita neobjavljena transliteracija.

13 Vlastita neobjavljena transliteracija.

14 Transliteracija i latinski izvornici preuzeti su iz korpusa za RCJHR (2000, 2014).
} 
češkome crkvenoslavenskom pisao Konzal (2012). Pojedinim su se konstrukcijama ili prijevodom pojedinih tekstova bavili i Badurina Stipčević (2006, 2009, 2012), Corin (1995), Eterović (2014), Eterović i Vela (2013), HCSJ (2014), Mihaljević, A. (2014, 2018), Mihaljević, M. (2006, 2009), Mihaljević i Reinhart (2005), Reinhart (1993), Скупский (1993), Spurná (2014), Turkalj (2012), Vrtič (2009). U ovome se radu na jednome mjestu na reprezentativnom broju raznovrsnih hrvatskoglagoljskih biblijskih i nebiblijskih tekstova donose prijevodne inačice latinske konstrukcije ablativa apsolutnoga. Detaljniji pregled bavljenja sintaksom hrvatskoga crkvenoslavenskog v. u Mihaljević, M. (2018).

\section{Ablativ apsolutni preveden dativom apsolutnim}

U tekstovima je potvrđen niz primjera u kojima se ablativ apsolutni prevodi istovrijednom crkvenoslavenskom konstrukcijom dativom apsolutnim. Prvi se opis dativa apsolutnoga pojavljuje već u gramatici M. Smotric'koga (1619). O podrijetlu konstrukcije dugo se raspravljalo i postojala su dva oprečna stava. ${ }^{15}$ Jedan je da je riječ o izvornoj crkvenoslavenskoj konstrukciji, dok je drugi da je riječ o utjecaju grčkoga genitiva apsolutnoga. ${ }^{16}$ Proučavatelji koji su zastupali stav da je riječ o izvornoj slavenskoj konstrukciji ističu da se dativ apsolutni upotrebljava u širemu značenju od grčkoga genitiva apsolutnoga, da apsolutne konstrukcije postoje i u drugim indoeuropskim jezicima, a ne samo u grčkome te da $u$ mnogim živim jezicima postoje ostatci konstrukcije dativa apsolutnoga. S druge strane autori koji smatraju da je dativ apsolutni posljedica grčkoga utjecaja ističu da se on uglavnom pojavljuje u tekstovima prevedenim $\mathrm{s}$ grčkoga na mjestima na kojima je u tekstu izvornika upotrijebljen apsolutni genitiv. ${ }^{17}$ Riječ je o konstrukciji koja se u hrvatskoglagoljskim tekstovima pojavljuje do 13. st. $^{18}$, ali i nakon toga prepisuje se u rukopisima ${ }^{19}$. Neovisno o tome koje je podrijetlo dativa apsolutnoga, on se u tekstovima iz ovoga

\footnotetext{
15 Stanislav (1933/1934).

16 O mogućnostima rekonstrukcije podrijetla apsolutnih konstrukcija u PIE v. Ruppel 2012.

17 O podrijetlu i izvornosti dativa apsolutnoga v. Скупский 1993. U Mihaljević, M. (2006: 223-224, 228-229) ističe se da je dativ apsolutni znatno češći u tekstovima prevedenima s grčkoga jezika.

18 Mihaljević, M. 2006: 224; 2009: 339, 341; Mihaljević, Reinhart 2005: 67; Reinhart 1993: 121.

19 Mihaljević, M. u tisku.
} 
korpusa pojavljuje većinom pod latinskim utjecajem, tj. on je vrlo često prijevodna istovrijednica za latinski ablativ apsolutni. Kao i ablativ apsolutni i dativ apsolutni najčešće ima vremensko značenje i u kanonskim tekstovima ${ }^{20}$ i u hrvatskome crkvenoslavenskom ${ }^{21}$.

U pravilu se pri prevođenju ablativa apsolutnoga prati i latinski red riječi premda se $u$ latinskome $u$ nekim primjerima particip pojavljuje ispred, a u nekima iza imenice s kojom se slaže. Particip se prezenta $u$ ablativu apsolutnome najčešće prevodi aktivnim participom prezenta: te enim recedente recedam, te veniente veniam, te quiescente quiescam - De s. Maria Magdalena: i iduĉu tebê idu s toboû, vraĉaûcu se tebê s tobô̂ vraĉu se i tebê počivaûĉu počinu i azb - CŽg 109r / iduĉu tebi idu s toboû, vraĉâ̂ci se $t(e) b i$ vraĉu se s toboû, $t(e) b i$ že počivaûĉu počinu - CIvan $115 \mathrm{v}$, illis loquentibus - Est 6,14: imb g(lago)lûcimb - $\mathrm{BrN}_{2} 238 \mathrm{~b}$, et cunctis Iudaeis, ..., flentibus - Est 3,15: a vs(ê)mb iûdêomb ... plačucimb - $\mathrm{BrN}_{2} 237 \mathrm{a}$, Regnante Demetrio - 2Mach 1,7: c(êsa)rstvuûcu dmitriû - BrVO 421d, Ionatha inchoante, ceteris autem respondentibus. - 2Mach 1,23: i onatu začenûcu · a pročimb otveĉaûcimb - BrVO 422d, obsistente sibi principe sacerdotum - 2Mach 3,4: protiveĉu sebê arhierêû - BrVO 424d, Beata Maria semper vergine intercedente - Or.: $b(l a) z ̌(e)$ noi $m(a)$ rii vsagda d(e)vi $m(o)$ leceei - CPar 196v; Dicente apostolo - Reg. s. Benedicti: g(lago)lûcu ap(osto)lu - RegBen 3r, Sed his malis praevenientibus - Hom. s. Gregorii papae: na simb zalimb prihodeĉimb $-\mathrm{BrN}_{2}$ 337c. Ablativ se apsolutni može prevesti dativom apsolutnim i kad uz particip dolazi objekt: adhuc loquente Iuda haec - 1Mach 4,19: oĉe g(lago)luĉu iûdê siê - BrVO 417a, rege et Aman celebrante convivium - Est 3,15: <...> amanu čbsteĉu brakb - $\mathrm{BrN}_{2}$ 236d-237a. Taj se objekt doslovno prevodi na hrvatski crkvenoslavenski.

Rjeđe se particip prezenta prevodi i prvim aktivnim participom preterita: appropinquante autem illo - De s. Maria Magdalena: približšu se emu - CIvan 120v, succedente Lysimacho fratre suo - 2Mach 4,29: pod'stupivšu lêzimaku bratu svoemu - BrVO 428bc, najčešće kad je riječ o glagolima čije se značenje doživljava kao kratkotrajno i kad je u latinskome riječ o prefigiranim glagolima.

Ablativ apsolutni s participom perfekta rjeđe se prevodi dativom apsolutnim. Najbliži je formalni korespondent latinskomu participu perfekta

20 Stanislav 1933/1934: 8-10.

21 Mihaljević, M. 2009: 339. 
pasivnomu pasivni particip preterita, kojim se zadržava pasivnost konstrukcije: Iesu cognito - Hom. s. Gregorii papae: is(us) u poznanomu - BrVO 75b. U primjeru Interfecto autem Domitiano - Hom. s. Hyeronimi: ub'enu že suĉu dometiênu - $\mathrm{BrN}_{2}$ 418d participu se dodaje i aktivni particip prezenta glagola biti, ali se i dalje zadržava pasivnost. Ablativ apsolutni s participom perfekta $\mathrm{u}$ primjeru evolutis aliquot dierum curriculis - De s. Maria Magdalena: tako dnemb malêmb minuv'šimb - CŽg 108r preveden je dativom apsolutnim s prvim aktivnim participom preterita, ali tekst nije posve doslovno preveden $\mathrm{i}$ ne prati se vjerno red riječi. Dativ apsolutni s prvim aktivnim parrticipom preterita pojavljuje se kao prijevod ablativa apsolutnoga i u primjeru et tunc feriatis Iudaeis arma capere suis praecepit. - 2Mach 5,25: i togda prazdnuûcimb iûdêomb svoimb povelê oružiti se - BrVO 430d.

Pojava dativa apsolutnoga u tekstu može poslužiti za dataciju teksta jer ako se pojavljuje i tamo gdje u latinskome nije konstrukcija ablativa apsolutnoga, svjedoči o tome da je bio živom konstrukcijom u vrijeme nastanka teksta. S obzirom na to da je dativ apsolutni već u 13. stoljeću zastarjelicom, a u 14. se stoljeću više uopće ne upotrebljava ${ }^{22}$, takva uporaba dativa apsolutnoga dokazuje da je izvorni prijevod teksta morao nastati jako rano, najkasnije krajem 13. stoljeća. Takav je primjer iz Života Marije Magdalene $^{23}$ : rediens - De s. Maria Magdalena: i prišad'šu že nemu - CŽg $114 \mathrm{v} /$ greduĉu emu - CIvan 121r. Primjer iz Života Marije Magdalene u dvama se zbornicima prevodi različitim participima - u Žgombićevu zborniku prevodi se participom preterita, a u Ivančićevu zborniku participom prezenta. U primjeru unius diei et noctis cursu consummato - De s. Maria Magdalena: hodeĉimb imb edan' danb i noĉ' - CŽg 109v / greduciim že imb ed'nogo d'ne i noĉi steĉeniemb - CIvan 116r ablativ se apsolutni cursu consummato ne prevodi doslovno. U Ivančićevu se zborniku taj ablativ apsolutni prevodi instrumentalom steĉeniemb. Međutim, u prijevodu se pojavljuje dativ apsolutni koji je možda potaknut apsolutnom konstrukcijom u latinskome, ali također svjedoči o živosti konstrukcije u vrijeme nastanka prijevoda. U tome se primjeru doslovno prevodi imenska skupina u genitivu koja se odnosi na ablativ apsolutni. Spurná (2004: 69) zaključuje da zbog maloga broja dativa apsolutnih treba pretpostaviti da je Regula sv. Benedikta kasno prevedena.

\footnotetext{
22 Mihaljević, Reinhart 2005: 66-67.

23 O dataciji Života Marije Magdalene na temelju pojave dativa apsolutnoga v. Mihaljević,
} A. 2014. 


\section{Ablativ apsolutni preveden instrumentalom apsolutnim}

Instrumental se često pojavljuje kao prijevodna istovrijednica za ablativ jer obuhvaća mnoga značenja ablativa te se zbog toga pojavljuje i u prijevodima ablativa apsolutnoga te postupno zamjenjuje dativ u apsolutnoj konstrukciji. Za razliku od dativa apsolutnoga, koji neki smatraju sintaktičkim grecizmom, instrumental se apsolutni može smatrati sintaktičkim latinizmom jer je pod izravnim utjecajem latinskoga ablativa. ${ }^{24}$

Latinski ablativ apsolutni s participom prezenta prevodi se instrumentalom apsolutnim najčešće u biblijskim tekstovima (Estera i Knjige o Makabejcima). Particip se u pravilu prevodi aktivnim participom prezenta: audiente rege atque principibus - Est 1,16: slišeĉimb c(êsa)remb tre vladikamb $-\mathrm{BrN}_{2} 235 \mathrm{~b}$, illo praesente - Est 6,1: imb tu buducimb $-\mathrm{BrN}_{2}$ 237d, me praesente - Est 7,8: mnoû tu buducimb - $\mathrm{BrN}_{2} 238$ c, et civibus ad murum convolantibus - 2Mach 5,5: i kolesnicami (sic!) k miri slêtaêcimi se BrVO 429d.

Rjeđe se u ablativu apsolutnome pojavljuje particip uz koji se veže objekt: Domino illi condignam retribuente poenam. - 2Mach 4,38: g(ospo)demb emu - edinako dostoinuû muku vzdaûcimb - BrVO 428d-429a. U tome se slučaju objekt prevodi doslovno.

U tekstu Život Marije Magdalene instrumental apsolutni izmjenjuje se s dativom apsolutnim, što svjedoči o postupnome prelasku s dativa na instrumental. U tome je tekstu jedan primjer instrumentala apsolutnoga s participom prezenta: domino disponente - De s. Maria Magdalena: g(ospo)demb vodeĉimb - CŽg 111 r.

Rjeđe se particip prezenta prevodi prvim aktivnim participom preterita: apparente omnipotente Domino - 2Mach 3,30: êviv'šim se vsemogucimb $b$ (ogo)mb - BrVO 426b, Turbis autem insurgentibus - $2 \mathrm{Mach}$ 4,40: narodom že stav'šimb - BrVO 429a. U tim je primjerima riječ o participu prefigiranih glagola, čije se trajanje doživljava kao vrlo kratko te se vjerojatno zato prevodi prošlim participom. U svim se primjerima prati latinski red riječi.

Ablativ apsolutni s participom perfekta često se prevodi instrumentalom apsolutnim, osobito u biblijskim tekstovima. Kao istovrijednica se latinskoga participa perfekta uglavnom pojavljuje pasivni particip preterita:

24 Tandarić 1993: 103-104. 
his ita gestis - Est 2,1: simi že t(a)ko dêênimi - $\mathrm{BrN}_{2} 235$ c, expletis omnibus Est 2,12: $i$ ispl'nenimi vs(ê)mi - $\mathrm{BrN}_{2}$ 235d, ablato sacco - Est 4,4: otnetim' vrêtiĉemb $-\mathrm{BrN}_{2}$ 237a, accitoque Athach eunucho - Est 4,5: prizvanimb že atagomb emnuhomb - $\mathrm{BrN}_{2}$ 237a, lugens et operto capite - Est 6,10: plače pokrivenoû gl(a)voû - $\mathrm{BrN}_{2} 238 \mathrm{a}$, divino responso ad se facto comitari secum 2Mach 2,4: b(o)žs'tvanimb otveĉaniemb $\cdot k$ nemu stvorenomb nositi sb soboû $\mathrm{BrVO} 423 \mathrm{bc}$, Et his dictis - 2Mach 3,34: i simi rečenimi - BrVO 426c, apprehensa civitate - 2Mach 5,5: êtimb gradomb - BrVO 429d, His itaque gestis - 2Mach 5,11: simi takoe dêênimi - BrVO 430a, Multis autem sacrilegiis in templo a Lysimacho commissis Menelai consilio, et divulgata fama, congregata est multitudo adversum Lysimachum multo iam auro exportato - 2Mach 4,39: mnozi (sic!) že s(ve)totad'bami v crêkvi ot lêzimaka stvorenimi - menelaovimb svêtomb - i prost'rtimb glasomb sabrano bistb množastvo protivb lêzimaku . mnogimb ûže zlatomb iznesenimb - BrVO 429a, relicto suffecto uno ex comitibus suis Andronico - 2Mach 4,31: ostavlenimb podb nareeniemb edinimb ot drugovb · is' družabnikovb svoihb - BrVO 428c, datis dextris - 2Mach 4,34: i danimi desnicami - BrVO 428d, sed contempto templo, et sacrificiis neglectis - 2Mach 4,14: neroždenoû cr(ê)kvoû i žr'tvami nebrêženimi - BrVO 427c, Misso autem in Aegyptum Apollonio Mnesthei filio - 2Mach 4,21: poslanim že v' jipatb apoloniemb $\cdot$ nesteovimb s(i)nomb - BrVO 428a, amotis his - 2Mach 4,11: ot'netimi simi - BrVO 427b, hostia Deo oblata, et votis magnis promissis ei - 2Mach 3,35: žrtvoû b(og)u prinesenoû - i obêti velimi obeĉanimi emu $\mathrm{BrVO} 426 \mathrm{~cd}$, repulsis adversitatibus - Or.: otpuenimi protivnimi - $\mathrm{MVat}_{4}$ 269d, Acceptisque a rege mandatis - 2Mach 4,25: prietimi že ot krala povelen'i - $\mathrm{BrN}_{2}$ 247c, assumptis Iason non minus mille viris - 2Mach 5,5: poêtimi êzonb tisuĉe muži - BrVO $429 \mathrm{~cd}$, mille et octingentis ablatis de templo talentis - 2Mach 5,21: tisuĉi osmb desetb otnetimi iz' cr(ê)kve talanti - BrVO 430c, manifesta Dei cognita virtute - $2 \mathrm{Mach} 3,28$ : b(o)žieû poznanoû siloû - BrVO 426b.

Rjeđe ablativ apsolutni nije preveden doslovno, nego je promijenjen $\mathrm{u}$ instrumental apsolutni s prvim aktivnim participom preterita: Evoluto autem tempore - Est 2,15: izšad'šim' že tbgda vr(ê)m(e)nemb - $\mathrm{BrN}_{2} 236 \mathrm{a}$, duce quodam tyranno, aetate pariter et dementia provecto - 2Mach 4,40: voemb eterimb sil'nikom' vzrastomb ravni · i bez'pametno staravšim' se BrVO 429a, directis per abbates quosdam cisterciensis ordinis ad capitulum generale comminatoriis - Lectio in festo s. Thomae episc. et mart.: poslanimi listi po četirêh 'opatêh' čisterien'skago reda na kapituli vsego zbora listi prêt'benimi - BrVO 58c. U tim primjerima imenica koja je u latinskome u 
ablativu postaje subjektom glagola, pa se odabire glagol kojim se prenosi izvorno značenje, ali aktivnom strukturom. Ablativ apsolutni s participom perfekta deponentnoga glagola prevodi se instrumentalom apsolutnim $s$ prvim aktivnim participom preterita: mortuisque patre eius ac matre - Est 2,7: umrv'ši že o(tb)cemb ee i materiû - $\mathrm{BrN}_{2} 235 \mathrm{~d}$.

$\mathrm{U}$ pravilu se pri prevođenju ablativa apsolutnoga instrumentalom apsolutnim prati latinski red riječi.

\section{Ablativ apsolutni preveden participski}

Rjeđe se ablativ apsolutni s participom prezenta prevodi nominativnim oblikom participa i imenicom u nominativu: donec veniente abbate cum monachis processione honorifice sunt recepte. - De s. Maria Magdalena: doidêže opatb s' mnihi · i s' kliriki s' sl(a)voû m'nogoû prišad'še - CIvan 121v.

Nominativom participa prevode se i ablativi apsolutni s participom perfekta pasivnoga. U dvama je primjerima riječ o izricanju protoka vremena: evolutis aliquot dierum curriculis - De s. Maria Magdalena: mimošad'ši nikoliko d(b)ni - CIvan $114 \mathrm{v}$, annis... transactis - S. Antonii de Padua: l(ê)to ... preminuvb - $\mathrm{BrN}_{2}$ 428c. U primjeru spretis mundi oblectationibus - S. Antonii de Padua: blaz'ni mira ostav'lb - $\mathrm{BrN}_{2}$ 428d umjesto prvoga aktivnog participa preterita pojavljuje se drugi aktivni particip preterita. Ablativ je apsolutni preveden nominativom participa i imenice te koordiniranom sastavnom rečenicom u primjeru: stupentibus cunctis - De s. Maria Magdalena: i vsi videĉe i ustrašiše se - CIvan 121v.

Ablativ se apsolutni s participom preterita prevodi i tako da se latinski particip prevodi nominativom prvoga aktivnog participa preterita, a imenica u ablativu kao objekt ${ }^{25}$ : chlamide supposita - De s. Maria Magdalena: prostr'vb plaĉb - CIvan 117r, Invocato igitur salvatoris nomine - De s. Maria Magdalena: i v'zvav'sp(a)s(i)t(e)la · ime - CIvan 119v, Convocato igitur universo clero et sacerdote predicto - De s. Maria Magdalena: i sabravb $b(l a) z ̌(e) n i$ makšiminb erêi i d'êci · i erêê prie rečenago - CIvan $120 \mathrm{v}$, quo viso - De s. Maria Magdalena: koga uzriv' - CIvan 116v, ventris tui refecta ingluvie - De s. Maria Magdalena: nasitiv' t(ê)lo tvoe - CIvan 115r, quo audito - De s. Maria Magdalena: sie že slišavb - CŽg 111v / eže s'lišavb -

25 Takvi su primjeri zabilježeni i kao prijevod latinskoga ablativa apsolutnog u Misalu hruackome Šimuna Kožičića Benje (v. Eterović, Vela 2013: 14). 
CIvan 118r, conversis scripture verbis - S. Antonii de Padua: obraĉ' se pisma s(love)si - $\mathrm{BrN}_{2}$ 429a, agnita tanta luminis claritate - Ev. Nicod.: raz(u)miv'še g(ospod)nu veliku sv(ê)tlost' svbteĉu se - FgNicod 1c, Quibus ille auditis - 1Mach 4,27: ons že slišavb - BrVO 417b, Quibus auditis - Mart. s. Georgii: to že slišavb - FgGeorg Ad, Tu devicto mortis aculeo aperuisti credentibus regna coelorum - Hymn.: ti pobêdiv' smr'tnie muki otvoril' esi vêruûcim' kralev'stva $n(e) b(e) s k a-C P a r$ 135r, His itaque dictis demones aufugiunt - $\mathrm{BrCR} 8 \mathrm{v}$ : i se rekši bêsi sêmo i tamo raz'bêg'nuše se $-\mathrm{BrN}_{2} 388 \mathrm{~b}$, coacto (coadunto) concilio - Lectio in festo s. Thomae episc. et mart.: $i$ stvor'še vêce - $\operatorname{BrBer}_{2} 45 c$, accepta auctoritate ac potestate super omnem Aegyptum - Lectio de Josepho: priêm' oblast' nad' nêpriêtli svoimi - COxf $15 c$, Sublatis omnibus - 1Mach 1,24: otêmb vsa - $\mathrm{BrN}_{2} 239 \mathrm{~b}$.

$\mathrm{U}$ primjeru Obtenta igitur vix precibus superioris licentia - S. Antonii de Padua: želeniemb $m(o) l(i t b) v b$ višnihb proĉenie isprošb $-\mathrm{BrN}_{2} 428 \mathrm{~d}-429 \mathrm{a}$ ablativ apsolutni preveden je nominativom participa isprošb, pritom particip nije na mjestu latinskoga participa, nego iza imenske riječi, tj. na kraju rečenice. Primjer adito rege - 2 Mach 4,8: došadb $k$ c(êsa)ru - BrVO 427b prevoditelj ne prevodi vjerno slijedeći strukturu u latinskome tako da se imenca prevede kao objekt. U latinskome glagol adeo, adire najčešće dolazi s prijedlogom ad i akuzativom, ali može se pojaviti i samo $s$ akuzativom, što otvara mogućnost pasivnoga ablativa apsolutnoga. Prevoditelj u prijevod dodaje prijedlog $k$ jer glagol doći ne može imati akuzativnu dopunu. U primjeru accensisque animis - 2Mach 4,38: i raz'gnêvav se $d(u) h(o) m b-$ BrVO 428d imenica je prevedena instrumentalom imenice, vjerojatno pod utjecajem latinskoga ablativa. Latinski se red riječi prati u svim tekstovima osim u tekstu Službe u čast sv. Antunu Padovanskomu. Particip se prezenta pojavljuje i u primjeru: Quibus illi conspectis timuerunt valde - 1Mach 4,21: eže oni videĉe uboêše se velmi - BrVO 417b.

U primjeru et animis ira repletis - 2Mach 4,40: i dusi gnêva isplneni BrVO 429a i oblik imenice i oblik participa mogu biti i nominativ i instrumental, particip je u drugim brevijarima u instrumentalnome obliku: isplnenimi Vat ${ }_{5} 229$ c / $\mathrm{N}_{2}$ 248a.

\section{Ablativ apsolutni preveden prijedložnim izrazom}

Rjeđe se ablativ apsolutni prevodi i prijedložnim izrazima s različitim prijedlozima ovisno o smislu. I u suvremenome je hrvatskome jedna od prijevodnih istovrijednica ablativu apsolutnomu prijedložni izraz, najčešće 
$\mathrm{s}$ vremenskim prijedlozima tijekom, za, na, nakon i $\mathrm{sl}^{26}$. U korpusu su u prijedložnim izrazima kojima se prevodi ablativ apsolutni potvrđeni prijedlozi $v$ i meždu, koji mogu imati i vremensko i prostorno značenje: biennii spatio iam elapso - De s. Maria Magdalena: $v$ male prestoêne - CŽg $111 \mathrm{r}$ / v' mali pristoêni - CIvan $117 \mathrm{v}$, periclitantibus aliis - De s. Maria Magdalena: meû inemi is' pogibeli - CŽg 115r / v' pogibeli meû inimi CIvan 122r. Ablativ apsolutni s participom perfekta pasivnim prevodi se u Reguli sv. Benedikta i prijedložnim izrazom s prijedlogom po: Et data benedictione incipiant matutinos. - Reg. s. Benedicti: i po molitvi počnite sl(a)vu ûtrn 'nû - RegBen 19v, Intrantes et exeuntes hebdomadarii in oratorio mox matutinis finitis dominica omnium genibus provolvantur postulantes pro se orari. - Reg. s. Benedicti: izlizuĉe i vlizuĉe $n(e) d(\hat{e}) \operatorname{lnici}$ po ûtrni v n(e)d(ê)lni danb - vsei brat'i do kolêna poklonite se proseĉe m(o)liti za se - RegBen 23v, non permittatur explicito opere dei remorari in oratio. - Reg. s. Benedicti: emu se ne vzda proĉene po službi v cr(ê)kvi ostati - RegBen 34r. Prijedlog po u hrvatskome crkvenoslavenskom ima značenje vremenske susljednosti i česta je prijevodna istovrijednica prijedloga post. ${ }^{27}$ Zbog toga se susljednog značenja pojavljuje samo u prijevodima ablativa apsolutnih $s$ participom perfekta. U Reguli sv. Benedikta u prijedložnim se izrazima koji su prijevod latinskoga ablativa apsolutnoga pojavljuju i prijedlozi brezb i razve,${ }^{28}$ ali uz participe glagola koji označavaju izuzimanje ili uklanjanje (exceptis, sublata).

\section{Ablativ apsolutni preveden besprijedložnom imenskom skupinom}

Ablativ se apsolutni rjeđe prevodi i besprijedložnim instrumentalom. U instrumentalu stoji imenica značenjski bliska glagolu od kojega je particip u latinskome. Česte su imenice koje označavaju pomoć ili potporu. Imenica u ablativu prevodi se ili genitivom ili značenjski bliskim pridjevom: qualiter favente deo per singulos annos tota haec dies expendatur - In assumptione BVM, Sermo s. Hieronymi presb.: $k(a) k o$ se $b(o) z ̌ i e \hat{u}$ pomociiû na vsako l(ê)to $v$ si $d(b) n b$ sie ispravlaet' $-\mathrm{BrN}_{2} 468 c$, Deo auxiliante pugnare sufficiunt - Reg. s. Benedicti - b(o)žîu pomocîû moĉni su(tb) rvati se - RegBen 4 r, adiuvante

\footnotetext{
26 Gortan, Gorski, Pauš 2005: 247.

27 HCSJ 2014: 274.

28 V. Spurná 2004: 61-62.
} 


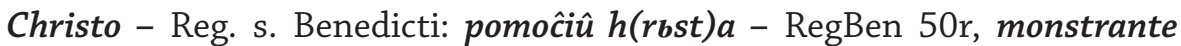
scriptura - Reg. s. Benedicti: kazaniemb s(veta)go pisma - RegBen 17r.

I ablativ apsolutni s participom perfekta rjeđe se prevodi besprijedložnim instrumentalom: et ob hoc profectus ex Aegypto efferatis animis, civitatem quidem armis cepit. - 2Mach 5,11: i sego radi pošadb iz' eûpta - i sverêpnimi dusi gradb vistinu oruženiemb priêtb - BrVO 430a, inclinato capite vel prostrato omni corpore in terra - Reg. s. Benedicti: pokloneniemb glavomb ili têlomb na z(e)mlû padeniemb - RegBen $34 \mathrm{v}$, et dissimulata ira Est 5,10: i raspačnimb gnêvomb - $\mathrm{BrN}_{2} 237$ c, Domino cum omni tranquillitate propitio facto illis - 2Mach 2,23: sb $g($ ospo)demb sa vsakoû tihostiû $\cdot \boldsymbol{m}(\mathbf{i}) \mathbf{l}(\mathbf{o})$ stivimb stvoreniemb imb - BrVO 424b, recepto exercitu - 2Mach 3,35: vzetiemb voev'stviemb - BrVO 426cd. U primjeru tactis sacrosanctis Lectio in festo s. Thomae episc. et mart.: kosn(e)niemb s(ve)tos(ve)tihb BrBer $245 \mathrm{~d}-46 \mathrm{a} /$ kasneniem' s(ve)tos(ve)timb - BrVO 58b u Brevijaru Vida Omišljanina sacrosanctis se prevodi kao pridjev koji stoji uz imenicu u instrumentalu, a u II. beramskome brevijaru imenicom u genitivu. Moguće je da je riječ o pogreški prepisivača, ali i da je u II. beramskome brevijaru s(ve)tos(ve)tihb supstantivirani imenski atribut, a u Brevijaru Vida Omišljanina $s$ (ve)tos(ve)timb pridjev koji se slaže s imenicom kasneniem'.

Latinski ablativ apsolutni može se pojavljivati i bez participa, ali uz ograničeni broj imenica koje označavaju čast, službu, djelatnost ili dob (consul, dux, rex, puer, senex...) i uz ograničeni broj pridjeva (vivus, salvus, plenus, invitus, ignarus). ${ }^{29} \mathrm{U}$ korpusu je malo primjera ablativa apsolutnoga bez participa. Takvi se ablativi apsolutni prevode instrumentalom. Kad je riječ o stranim imenima, ona se ne sklanjaju, nego u instrumentalu stoji samo opća imenica: Menelao ductore - 2Mach 5,15: menelausb voditelemb - BrVO 430b. U primjeru divina providentia duce, post labores multimodos perductus est in locum excelsum seorsum - In s. Francisci: b(o)ž(a)stv(e)nimb promotreniemb vodeĉ' se po trudêhb mnozêhb dovedenb bê $v$ mêsto visokoe na vrhb - BrVat $_{6}$ 188c imenica duce prevedena je nominativom participa glagola koji je značenjski blizak toj imenici, a druga imenska skupina prevedena je instrumentalom.

29 Gortan, Gorski, Pauš 2005: 249. 


\section{Ablativ apsolutni preveden nezavisnom rečenicom}

Jedna je od prijevodnih mogućnosti za prevođenje ablativa apsolutnoga nezavisna rečenica. U korpusu su nezavisne rečenice kojima se prevodi ablativ apsolutni ili povezane sastavnim veznikom ili je riječ o bezvezničkim ili samostalnim rečenicama.

Ablativ apsolutni s participom prezenta rjeđe se prevodi nezavisnim rečenicama. Primjer je ablativa apsolutnoga s participom prezenta prevedenim sastavnom rečenicom $s$ veznikom $i$ : recedentibus igitur praedictis viris - De s. Patricio: ti mnihi $i$ tud'e otidoše ot nego - COxf 47a. Ablativ apsolutni s participom prezenta preveden je samostalnom rečenicom u primjeru ab hora nona die sabbathi usque in diem lunae lucescente caelo clara luce - Epistola de caelo missa: ot devete godini soboti dokle po nedêli svane iže ne svane - CPar 293v-294r.

Češće se sastavnom ili samostalnom rečenicom prevode ablativi apsolutni s participom perfekta. Pritom se u većini primjera ablativ apsolutni prevodi aktivno, a imenica koja je dio konstrukcije prevodi se kao objekt aktivnoga glagola: draco ore aperto posuit os suum - Lectio s. Margaritae: zmii zinu i položi us'ta svoê - COxf 26b, Dicto etiam verso et benedicente abbate legantur aliae quattuor lectiones de novo testamento - Reg. s. Benedicti: i po nihb b(e)rš · i bl(agoslovle)nie v'zdaûtb $\cdot i$ čtite se $\cdot v \cdot(=3)$

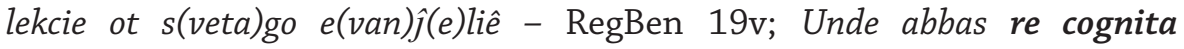
monachum ab officio deposuit - Mirac. s. Augustini ep.: $i$ to priurb poz'na $i$ m'niha ot mise ustavi - $\mathrm{BrN}_{2}$ 373a; Post magnam autem horam clausis oculis emisit lacrimas infinitas - In s. Elizabethi: po m'nozê že časê zatvori oči · i ispusti sl'zi - BrBer 1 154b; Interim dum dicitur Canticum Benedictus extinctis prius omnibus candelis praeter unam - Rub.: i prêžde neže svršetb m(a)t(uti)nu ugasetb svêce · vse razvê dvêû svêcu - BrVO 235b; recepta coniuge et puero De s. Maria Magdalena: poêtb ženu svoû - CŽg 112 / vzet' ženu - CIvan $118 \mathrm{v}$.

U nekim primjerima konstrukcija se prevodi povratno: toto corpusculo ante altaris prostrato - De s. Maria Magdalena: $\boldsymbol{i}$ tudie $\boldsymbol{t}(\hat{e}) l o$ ee $\operatorname{pr}(\hat{e}) d^{\prime}$ ol't [a]remb is'prostri se - CIvan 120v; Unde gravi quaestione supra iure ecclesiastico et regni consuetudinibus inter ipsum et regem anglorum exorta - Lectio in festo s. Thomae episc. et mart.: ot'nûdêže usil'na rasprb · o pravdê cr(ê)kvenoi ot zakona vladaniê meždû im' · i c(êsa)rem' ot anglie v'zdviže se - BrVO 58a.

Takva se konstrukcija prevodi i pasivnom rečenicom: posito super caput eius diademate - Est 1,11: položena že bê nb gl(a)vê ee kruna - $\mathrm{BrN}_{2} 235 \mathrm{a}$, 
nomine proprio perdito - De s. Maria Magdalena: bisi ime pravdnoe zagubleno - CŽg 106r, ostenso sibi caelitus indicio - Lectio in festo s. Thomae episc. et mart.: skazana emu bis(tb) zap(o)v(ê)db - BrVO 58d.

$\mathrm{U}$ primjeru apertoque occulto aditu templi ... et capitibus amputatis foras proiecerunt. - 2Mach 1,16: otvr'zaše otai vrat'ca crêkvi ... i glavi imb usêkoše i vr'goše vanb - BrVO 422b dva su ablativa apsolutna, koji su prevedeni sastavnom rečenicom, a imenice su objekt glagola.

U primjeru iz Službe u čast sv. Thomasu Becketu ablativ se apsolutni prevodi nezavisnom rečenicom u kojoj je imenica prevedena instrumentalom koji se smatra istovrijednicom latinskoga ablativa: Tandem morte sibi intentata - Lectio in festo s. Thomae episc. et mart.: i potom' iskahu $i$ semr'tiû - BrVO 58a. Pri prevođenju prevoditelji ne prepoznaju latinsku kolokaciju intento alicui mortem sa značenjem prijetiti komu smrću nego je prevode doslovno istovrijednicom glagola intento - iskati i instrumentalom imenice smrt, a kako bi doprinio smislu teksta pisar II. beramskoga brevijara u prijevodu dodaje infinitiv glagola umoriti, čime dobiva pleonastičnu konstrukciju.

\section{Ablativ apsolutni preveden zavisnom rečenicom}

Pri prevođenju ablativa apsolutnoga na suvremeni hrvatski najčešća je prijevodna istovrijednica zavisna rečenica. Već se u starocrkvenoslavenskome pri prevođenju grčkih apsolutnih konstrukcija pojavljuju vremenske rečenice. ${ }^{30}$ Međutim, u korpusu je malo primjera prevođenja ablativa apsolutnoga zavisnom rečenicom. Prevoditelj s latinskoga vjerojatno želi što vjernije zadržati strukturu izvornika, pa radije bira participske konstrukcije nego zavisnu rečenicu.

Ablativ se apsolutni s participom perfekta prevodi vremenskom zavisnom rečenicom $\mathrm{s}$ najčešćim vremenskim veznicima kada i egda. Primjeri su ablativa apsolutnoga prevedenih vremenskom rečenicom $s$ veznikom kada najčešći u Reguli sv. Benedikta: Ergo his omnibus humilitatis gradibus ascensis monachus mox ad caritatem dei pervenit illam. - Reg. s. Benedicti: i t'gda kada koludar' vse skaline umileniê izlize · pridetb k lûbosti

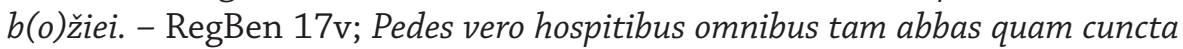
congregatio lavet, quibus lotis hunc versum dicant - Reg. s. Benedicti: i nozê gostemb op (a)tb i brat'ê vsi umivajte · i kada nogê umiûtb $\cdot r^{\prime}$ cite sb b(e)ršb -

30 HCSJ 2014: 311. 
RegBen 35r. Particip je perfekta u latinskome pasivan. U primjerima iz Regule sv. Benedikta konstrukcija se prevodi aktivno, a imenica koja je u ablativu u izvornoj konstrukciji postaje objekt aktivnoga glagola. U primjeru Facto autem primo signo horae nonae disiungant se ab opere suo singuli. - Reg. s. Benedicti: i kada prvi zvonb na nonu udri . ostavivše dêlo svoe budite gotovi - RegBen $31 \mathrm{v}$ u kojemu se ablativ apsolutni prevodi vremenskom rečenicom s kada imenica se prevodi kao subjekt glagola, ali se ni ta imenica ni particip ne prevode svojom najbližom istovrijednicom kako bi se zadržao izvorni smisao. Ablativ se apsolutni prevodi vremenskom rečenicom i u tekstu Čistilište svetoga Patricija, u kojemu konstrukcija nije doslovno prevedena, nego je prepričana: mortuo Patricio - De s. Patricio: kada se biše ûre b(la)ž(e)ni patricii ot sega s(vi)ta prestavil' - COxf 47a. Vremenska rečenica s veznikom egda kao prijevod ablativa apsolutnoga pojavljuje se također u Reguli sv. Benedikta, u kojoj se mnogo češće pojavljuje veznik kada: Qua perfecta respondeant omnes Amen. - Reg. s.

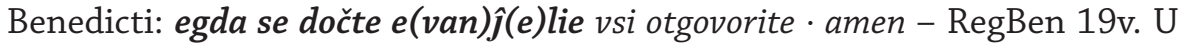
toj se rečenici latinska pasivna konstrukcija prevodi povratno. U primjeru quando Nehemias aedificato templo et altari obtulit sacrificia. - 2Mach 1,18: egda noemiê sazda oltarb · i cr(ê)kvi prinese žr'tvi - BrVO 422c vremenska je rečenica vjerojatno i potaknuta pojavom vremenskoga veznika quando. U Reguli sv. Benedikta ablativ apsolutni s participom prezenta katkad se također prevodi vremenskom rečenicom s veznikom kada: Exsurgamus ergo tandem aliquando excitante nos scriptura ac dicente. - Reg. s. Benedicti: ûre vstanimo n(i)ne kada vzove nasb pismo govoreĉe. - RegBen $1 \mathrm{v}$.

Na suvremeni hrvatski ablativ apsolutni može se prevesti i drugim vrstama zavisnih rečenica (pogodbena, dopusna, uzročna...), međutim, takvi primjeri nisu zabilježeni. U korpusu je potvrđen jedan ablativ apsolutni bez participa preveden poredbenom rečenicom: scriptura teste - S. Antonii de Padua: êkože pis'mo svêdokuetb - $\mathrm{BrN}_{2}$ 429a. U primjeru Omnibus venientibus sive discedentibus hospitibus - Reg. s. Benedicti: vsimb gostestemb (sic!) ki prihode - ili othodetb - RegBen $34 \mathrm{v}$ ablativ je apsolutni preveden imenicom u dativu uz koju je odnosna rečenica uvedena veznikom $k i$. Ostali su ablativi apsolutni u toj rečenici prevedeni imenskom skupinom u instrumentalu. 


\section{Zaključak}

Većina prevoditelja s latinskoga na hrvatski crkvenoslavenski pokušava što vjernije oponašati izvornu konstrukciju, zbog čega se ablativ apsolutni znatno češće prevodi apsolutnim konstrukcijama s dativom ili instrumentalom ili imenskom skupinom nego zavisnom ili samostalnom rečenicom. Unutar istoga teksta ablativ se apsolutni prevodi na različite načine. Zbog pojave ablativa u konstrukciji česti su prijevodi u kojima je barem jedna riječ u instrumentalu. Pojava instrumentala apsolutnoga rezultat je oponašanja latinske konstrukcije jer se instrumental doživljava kao istovrijednica ablativu. Zbog te je istovrijednosti instrumental osobito čest u biblijskim tekstovima. U latinskome particip može stajati i ispred i iza imenice, a prevoditelji često vjerno prenose latinski poredak. U ablativu se apsolutnome pojavljuje u latinskome particip prezenta aktivnoga i particip prezenta pasivnoga. U latinskim se gramatikama često navodi da particip prezenta označava radnju istodobnu s ostatkom rečenice, a particip perfekta radnju izvršenu prije radnje ostatka rečenice, međutim, taj je sustav u srednjovjekovnome latinskom donekle narušen jer se često participom prezenta označava radnja koja je neposredno prethodila radnji glavne rečenice. $S$ druge se strane particip prezenta često prevodi svršenim participom prošlim kad je riječ o prefigiranim glagolima i glagolima koje prevoditelj doživljava kao trenutačne (npr. veniente abbate: opatb prišad'še, evolutis aliquot dierum curriculis: tako dnemb malêmb minuv'šimb, recedentibus igitur praedictis viris: ti mnihi tud'je otidoše ot ńego). Reinhart (1993: 115125) navodi da su zamjene za apsolutne konstrukcije dativ apsolutni, zatim vremenska rečenica i instrumental apsolutni. Badurina Stipčević (2006: 53) ističe da se kao prijevod apsolutnih konstrukcija pojavljuje i particip u nominativu, što je potvrđeno i u korpusu.

Nekoliko je primjera u kojima se u latinskome pojavljuje ablativ apsolutni, ali on ili nije doslovno preveden ili je iskvaren višestrukim prepisivanjem ili je riječ o tome da prevoditelj pred sobom nije imao inačicu latinskoga teksta koja je nama dostupna. Takvi su primjeri: haec dicente David ad inferum - Ev. Nicod.: i bivšu semu - FgNicod 1c, aperto ostio cum clavi - De s. Patricio: i otklopiv' - COxf 47a, flexo palpite - S. Antonii de Padua: klečec $\boldsymbol{a}-\mathrm{BrN}_{2} 429 \mathrm{~b}$.

Prijevodne mogućnosti za prevođenje ablativa apsolutnoga prikazane su i tablično. 


\begin{tabular}{|c|c|c|}
\hline $\begin{array}{l}\text { prijevodna } \\
\text { inačica }\end{array}$ & $\begin{array}{l}\text { particip prezenta aktivnoga } \\
\text { u latinskome izvorniku }\end{array}$ & $\begin{array}{l}\text { particip perfekta pasivnoga } \\
\text { u latinskome izvorniku }\end{array}$ \\
\hline $\begin{array}{l}\text { dativ } \\
\text { apsolutni }\end{array}$ & $\begin{array}{l}\text { najčešće aktivni particip } \\
\text { prezenta } \\
\text { rijetko: prvi aktivni particip } \\
\text { preterita (najčešće prefigirani i } \\
\text { kratkotrajni glagoli) } \\
\text { svi tekstovi } \\
\end{array}$ & $\begin{array}{l}\text { rijetko } \\
\text { pasivni particip preterita } \\
\text { nebiblijski tekstovi }\end{array}$ \\
\hline $\begin{array}{l}\text { instrumental } \\
\text { apsolutni }\end{array}$ & $\begin{array}{l}\text { rjeđe od dativa apsolutnoga } \\
\text { aktivni particip prezent } \\
\text { rjeđe: prvi aktivni particip } \\
\text { preterita (najčešće prefigirani i } \\
\text { kratkotrajni glagoli) } \\
\text { biblijski tekstovi }\end{array}$ & $\begin{array}{l}\text { često, osobito u biblijskim } \\
\text { tekstovima } \\
\text { pasivni particip preterita } \\
\text { rjeđe: prvi aktivni particip } \\
\text { preterita }\end{array}$ \\
\hline participski & $\begin{array}{l}\text { rijetko } \\
\text { nominativ prvoga aktivnog } \\
\text { participa preterita i imenica u } \\
\text { nominativu - Život Marije } \\
\text { Magdalene }\end{array}$ & $\begin{array}{l}\text { nominativ prvoga aktivnog } \\
\text { participa preterita i imenica u } \\
\text { akuzativu (svi tekstovi) } \\
\text { rijetko: nominativ prvoga } \\
\text { aktivnog participa preterita i } \\
\text { imenica u nominativu } \\
\text { (nebiblijski tekstovi) }\end{array}$ \\
\hline $\begin{array}{l}\text { prijedložni } \\
\text { izraz }\end{array}$ & $\begin{array}{l}\text { rijetko } \\
\text { v, meû - Život Marije Magdalene }\end{array}$ & \begin{tabular}{|l|} 
rijetko \\
po, uz glagole koji označavaju \\
izuzimanje: brezb, razvê \\
- Regula sv. Benedikta \\
v, meû - Život Marije Magdalene
\end{tabular} \\
\hline $\begin{array}{l}\text { besprijedložna } \\
\text { imenska } \\
\text { skupina }\end{array}$ & \begin{tabular}{|l|} 
rijetko \\
instrumental \\
većinom Regula sv. Benedikta
\end{tabular} & $\begin{array}{l}\text { rijetko } \\
\text { instrumental }\end{array}$ \\
\hline $\begin{array}{l}\text { nezavisna } \\
\text { rečenica }\end{array}$ & $\begin{array}{l}\text { rijetko } \\
\text { sastavna ili bezveznička } \\
\text { rečenica }\end{array}$ & \begin{tabular}{|l} 
češće \\
aktivna rečenica - imenica \\
postaje objekt \\
rečenica s povratnim glagolom \\
pasivna rečenica - ima i \\
biblijskih primjera \\
sastavna ili bezveznička \\
rečenica \\
nebiblijski tekstovi
\end{tabular} \\
\hline
\end{tabular}




\begin{tabular}{|l|l|l|}
\hline $\begin{array}{l}\text { prijevodna } \\
\text { inačica }\end{array}$ & $\begin{array}{l}\text { particip prezenta aktivnoga } \\
\text { u latinskome izvorniku }\end{array}$ & $\begin{array}{l}\text { particip perfekta pasivnoga } \\
\text { u latinskome izvorniku }\end{array}$ \\
\hline $\begin{array}{l}\text { zavisna } \\
\text { rečenica }\end{array}$ & $\begin{array}{l}\text { vremenska rečenica s } \\
\text { veznikom kad: vrlo rijetko } \\
\text { - Regula sv. Benedikta } \\
\text { jedan primjer odnosne rečenice } \\
\text { iz Regule sv. Benedikta }\end{array}$ & $\begin{array}{l}\text { vremenska rečenica s } \\
\text { veznicima kad i egda: rijetko } \\
\text { - Regula sv. Benedikta } \\
\text { jedan primjer iz biblijskoga } \\
\text { teksta }\end{array}$ \\
\hline \multicolumn{2}{|c|}{ ablativ apsolutni bez participa (vrlo rijetko) } \\
\hline $\begin{array}{l}\text { instrumental imenske skupine (nesklonjivo ime) - biblijski tekst } \\
\text { instrumental + povratni glagol u participu prezenta aktivnoga (In s. Francisci) } \\
\text { poredbena rečenica (S. Antonii de Padua) }\end{array}$ \\
\hline
\end{tabular}

\section{Popis kratica}

$\mathrm{BrBer}_{1}$ - I. beramski brevijar, kraj 14. st.

$\mathrm{BrBer}_{2}$ - II. beramski brevijar, 15. st.

$\mathrm{BrN}_{2}$ - II. novljanski brevijar, 1495.

BrVat $_{6}$ - Vatikanski brevijar Illirico 6, sredina - kraj 14. st.

BrVO - Brevijar Vida Omišljanina, 1396.

CIvan - Ivančićev zbornik, 14. - 15. st.

COxf - Oksfordski zbornik, 15. st.

CPar - Pariški zbornik, 1375.

CŽg - Žgombićev zbornik, 16. st.

FgGeorg - Krčki fragmenti Pasionala, Fragment mučenja sv. Jurja

FgNicod - Odlomci zbornika, 15. st.

$\mathrm{MVat}_{4}$ - Vatikanski misal Illirico 4, početak 14. st.

RegBen - Regula sv. Benedikta, kraj 14. st.

\section{Literatura}

Badurina Stipčević, Vesna (2006) „Knjige o Makabejcima u hrvatskoglagoljskoj književnosti: Prva Knjiga o Makabejcima u hrvatskoglagoljskim brevijarima”, Slovo, 54-55, 5-126.

Badurina Stipčević, Vesna (2009) „Knjige o Makabejcima u hrvatskoglagoljskoj književnosti: Druga knjiga o Makabejcima u hrvatskoglagoljskim brevijarima", Slovo, 59, 1-75. 
Badurina Stipčević, Vesna (2012) Hrvatskoglagoljska Knjiga o Esteri, Matica hrvatska, Zagreb.

Corin, Andrew R. (1995) „The dative absolute in Old Church Slavonic and Old East Slavic", Die Welt der Slaven, 40, 251-284.

Eterović, Ivana (2014) „Dativ apsolutni u Misalu hruackom Šimuna Kožičića Benje”, Riječki filološki dani 9, ur. Diana Stolac, Rijeka, 357-365.

Eterović, Ivana, Jozo Vela (2013) „Sintaktičke funkcije participa u Misalu hruackome Šimuna Kožičića Benje”, Slovo, 62, 1-22.

Gortan, Veljko, Oton Gorski, Pavao Pauš (2005) Latinska gramatika, Školska knjiga, Zagreb.

HCSJ (2014) Hrvatski crkvenoslavenski jezik, prir. Milan Mihaljević, Hrvatska sveučilišna naklada, Staroslavenski institut, Zagreb.

Konzal, Václav (2012) „Latinské ablativ absolutní ve staroslověnském překladu. (Responze latinské syntaxe $\mathrm{v}$ českocírkevněslovanských památkách III.)", Slavia 81, 190-204.

Mihaljević, Ana (2014) „Hrvatskoglagoljski Život Marije Magdalene u odnosu na latinski predložak", Ricerche slavistiche 58, 213-293.

Mihaljević, Ana (2018) Sintaksa hrvatskoglagoljskih tekstova prevedenih s latinskoga, doktorska disertacija, Filozofski fakultet Sveučilišta u Zagrebu.

Mihaljević, Milan (2006) „Sintaktička svojstva najstarijih hrvatskoglagoljskih fragmenata", Mnogokratnite prevodi v južnoslavjanskoto srednovekovie, gl. ur. Lora Taseva, GoreksPres, Sofija, 221-239.

Mihaljević, Milan (2009) „Hrvatski crkvenoslavenski jezik”, Povijest hrvatskoga jezika 1: Srednji vijek, ur. Stjepan Damjanović, Društvo za promicanje hrvatske kulture i znanosti CROATICA, Zagreb, 283349.

Mihaljević, Milan (2018) „Sintaktička istraživanja hrvatskoglagoljskih tekstova: stanje i perspektive", Вісник Львівського університету, Серія філологічна, Випуск 69, 66-74.

Mihaljević, Milan (u tisku) „Absolute Constructions in the Second Beram (Ljubljana) Breviary", Zbornik konferencije Traces of Latin, Greek and Church Slavonic in Slavonic Syntax.

Mihaljević, Milan, Johannes Reinhart (2005) „The Croatian Redaction: Language and Literature", Incontri linguistici 28, 31-83. 
Müller-Lancé, Johannes (1994) Absolute Konstruktionen vom Altlatein bis zum Neufranzösischen: Ein Epochenvergleich unter Berücksichtigung von Mündlichkeit und Schriftlichkeit, Narr, Tübingen.

RCJHR (2000) Rječnik crkvenoslavenskoga jezika hrvatske redakcije. I. sv. A vrêdb, Staroslavenski institut, Zagreb.

RCJHR (2014.) Rječnik crkvenoslavenskog jezika hrvatske redakcije. II. sv. vrêdbnb - zapovêdnica, Staroslavenski institut, Zagreb.

Reinhart, Johannes (1993) Untersuchungen zur Syntax des KroatischKirchenslavischen. Das glagolitiche Missale romanum, Habilitationsschrift, Universität Wien.

Ruppel, Antonia (2012) Absolute Constructions in Early Indo-European. Cambridge University Press, Cambridge.

Скупский, Борис (1993) „Происхождение дательного самостоятельного в первоначальном славянском переводе евангелия", Slovo, 41-4243, 49-59.

Smotric'kij, Meletij (1619) Gramatiki slavenskija pravilnoe syntagma..., http://litopys.org.ua/smotrgram/sm.htm, posjet 23. svibnja 2019.

Spurná, Kateřina (2004) „Překladová technika ablativu absolutního v charvátskohlaholské Řeholi sv. Benedikta", Slovo, 64, 57-78.

Stanislav, Ján (1933/1934) „Datív absolutný v starej cirkevnej slovančine”, Byzantoslavica 5, 1-112.

Tandarić, Josip (1983) „Crkvenoslavenska jezična norma u hrvatskoglagoljskom ritualu”, Slovo, 32-33, 53-83.

Tandarić, Josip (1993) Hrvatsko-glagoljska liturgijska književnost, Kršćanska sadašnjost, Provincijalat franjevaca trećoredaca, Zagreb.

Turkalj, Lucija (2017) „Sintaksa aktivnih participa u hrvatskome crkvenoslavenskom jeziku", Slovo, 67, 113-141.

Vrtič, Ivana (2009) „Sintaktičke funkcije participa u Katančićevu prijevodu Svetoga pisma", Rasprave Instituta za hrvatski jezik i jezikoslovlje, 35, 1, 365-382.

Vulgata, http://www.drbo.org/lvb/index.htm, posjet 15. svibnja 2019. 


\section{SUMMARY}

\section{Ana Mihaljević}

\section{TRANSLATION OF THE LATIN ABLATIVE ABSOLUTE IN CROATO-GLAGOLITIC TEXTS}

In this paper we analyse the translations of the Latin ablative absolute in chosen Croato-Glagolitic texts that were translated from Latin. Ablative absolute is most frequently translated with the help of the Croatian Church Slavonic absolute structures in the dative or instrumental case. Dative absolute is an older structure and its appearance in a translation can be used to date it. The instrumental case appears in the translations because the translators see it as the Croatian Church Slavonic equivalent of the ablative. In the analysed translations absolute constructions were used more frequently than dependent clauses, which are nowadays used as translation equivalents in order to remain as close as possible to the original text. When translating the ablative absolute with the help of absolute constructions the word order from the original is closely mirrored. The Latin participle which is a part of that construction is translated by the present or past participle. Present participle is often translated by the past participle of perfective verbs when dealing with prefixed verbs and verbs which are considered as momentary by the translator (e.g. veniente abbate: opatb prišad'še).

Key words: Croatian Church Slavonic; ablative absolute; dative absolute; instrumental absolute 